\title{
ANALISIS RISIKO PAPARAN DEBU TERHADAP KESEHATAN, KESELAMATAN KERJA PADA PEKERJA PRODUKSI BETON
}

\author{
Jodi Irawan \\ Jurusan Teknik Lingkungan, Fakultas Arsitektur Lanskap dan Teknologi Lingkungan, \\ Universitas Trisakti, Jakarta, Indonesia \\ Email korespondensi: jodi08212035@trisakti.ac.id
}

\begin{abstract}
ABSTRAK
Penulisan karya ilmiah ini memiliki tujuan untuk menganalisis risiko paparan debu terhadap kesehatan, dan keselamatan kerja pada bagian produksi beton. Dari hasil analisis paparan debu menggunakan metode sampling menggunakan High Volume Air Sampler (HVAS) dengan nilai ambang batas (NAB) adalah $10000 \mu \mathrm{g} / \mathrm{Nm}^{3}$ dan/atau sama dengan $1 \mathrm{mg} / \mathrm{m}^{3}$. Dari hasil analisis paparan debu terhadap pekerja produksi beton di XXX didapatkan hasil yang melebihi NAB yang ditetapkan pada Peraturan Menteri Tenaga Kerja dan Transmigrasi No.13 Tahun 2011 tentang Nilai Ambang Batas Faktor Fisika dan Faktor Kimia Di Tempat Kerja.
\end{abstract}

Kata Kunci: Risiko paparan debu, Produksi Beton, Lingkungan

\section{PENDAHULUAN}

Pembangunan merupakan suatu usaha manusia untuk meningkatkan kualitas hidupnya menjadi lebih berkembang khususnya pembangunan tempat tinggal seperti rumah, apartemen, dll. Pembangunan infrastruktur akhir-akhir ini sedang berkembang dengan pesat khususnya di Indonesia karena banyaknya permintaan dari konsumen akan pembangunan ini. Ada berbagai macam jenis konstruksi yang bisa digunakan pada pembangunan suatu gedung, salah satunya peggunaan konstruksi beton pracetak. Dalam penerapan konstruksi beton pracetak mengalami perkembangan yang sangat pesat di dunia, termasuk di Indonesia. (Tampubolon, 2015)

Dalam pembangunan infrastruktur sendiri sering terjadi kecelakaan kerja, kecelakaan kerja yang terjadi di lingkungan kerja tidak hanya disebabkan karena kelalaian dari para pekerja saja, melainkan juga dapat disebabkan dari peralatan yang digunakan saat bekerja.

Pelaksanaan Keselamatan dan Kesehatan Kerja (K3) adalah salah satu bentuk upaya untuk menciptakan tempat kerja yang aman, sehat, bebas dari pencemaran 
lingkungan,sehingga dapat mengurangi dan atau bebas dari kecelakaan kerja dan penyakit akibat kerja yang pada akhirnya dapat meningkatkan efisiensi dan produktifitas kerja.

Beton pracetak adalah suatu metode percetakan komponen secara mekanisasi dalam pabrik atau workshop dengan memberi waktu pengerasan dan mendaatkan kekuatan sebelum dipasang. (Iqbal Batubara, 2012)

Sistem struktur beton pracetak merupakan salahsatu alternatif teknologi dalam perkembangan konstruksi di Indonesia yang dapat mendukung efisiensi waktu, efisiensi energi, dan mendukung pelestarian lingkungan. (Siti Aisyah Nurjannah, 2011)

Penulisan karya ilmiah ini memiliki tujuan untuk menganalisis risiko paparan debu terhadap kesehatan dan keselamatan kerja pada pekerja produksi beton.

\section{TINJAUAN PUSTAKA}

Debu merupakan zat kimia padat yang disebabkan karena kekuatan alami dan mekanisme seperti pengolahan, penghancuran, pelembutan, pengepakan yang cepat, dan peledakan dari benda organik maupun benda anorganik. (suma'mur, 2009)

Menurut Departemen Kesehatan Republik Indonesia (2003) debu adalah partikel kecil yang dihasilkan oleh proses mekanis. Jadi pengertian debu adalah partikel berukuran kecil sebagai hasil dari proses alami dan mekanis.

Menurut (Khumaidah, 2009) Debu Industri yang terdapat dalam udara terbagi menjadi 2 yaitu:

a. Deposit particulate matter, merupakan debu yang hanya berada sementara di udara, parikel ini segera mengendap karena daya tarik bumi.

b. Suspended particulate matter, adalah partikel debu yang tetap berada di udara dan tidak mudah mengendap.

Menurut macamnya, debu diklasifikasikan atas 3 jenis yaitu:

a. Debu organik, debu organik merupakan debu yang berasal dari makhluk hidup.

b. Debu metal, adalah debu yang didalamnya mengandung unsur-unsur logam seperti $\mathrm{Pb}, \mathrm{Hg}, \mathrm{Cd}$, dan Arsen.

c. Debu mineral, debu mineral adalah debu yang didalamnya mengandung senyawa kompleks. 
Data jenis debu dapat dilihat pada tabel berikut:

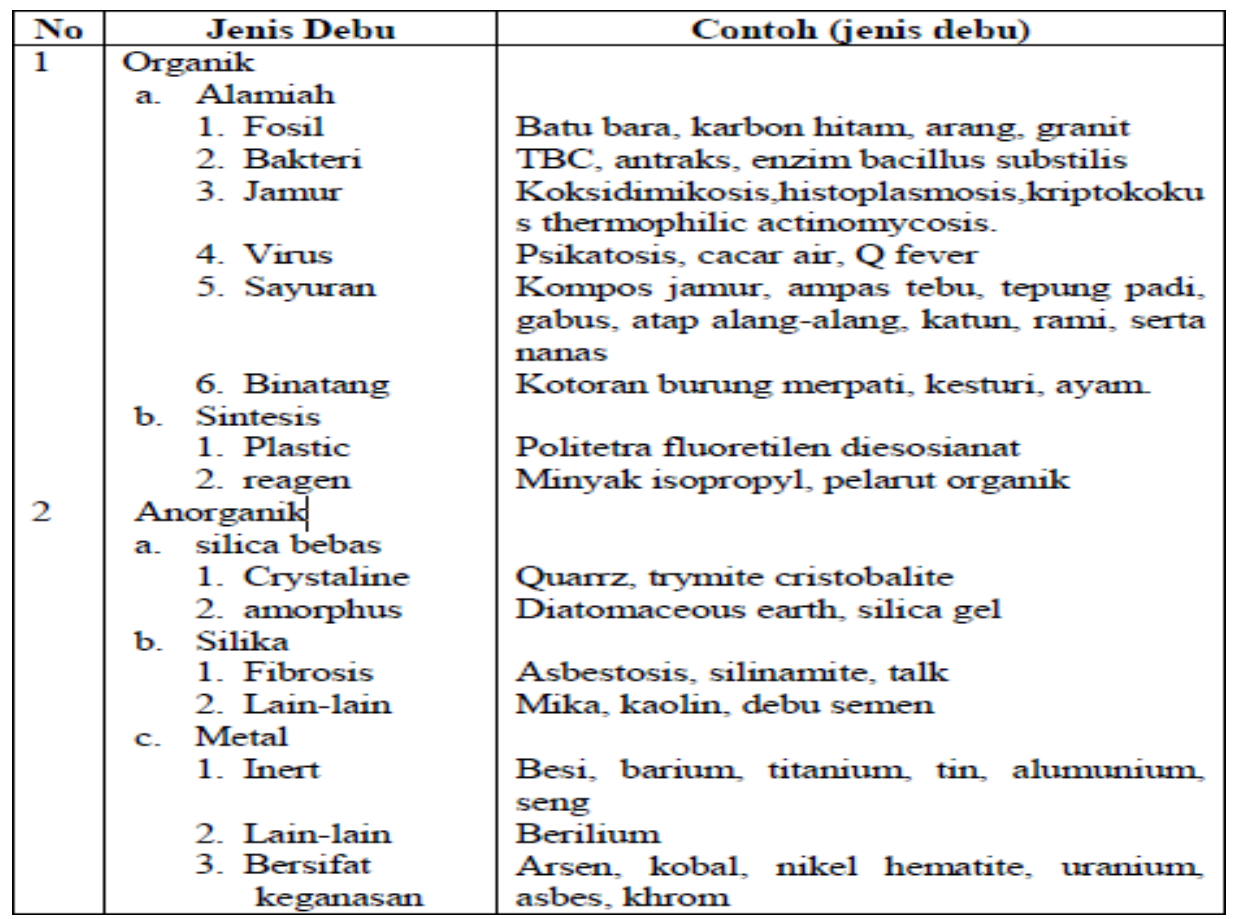

(Sumber: Khumaidah, 2009)

Pada dosis yang besar, debu bersifat merangsang dan menimbulkan reaksi. Reaksi tersebut berupa produksi lendir yang berlebihan, bila hal ini berlangsung dapat menimbulkan hiperplasi kelenjar mukus. Dan pada jaringan paru dapat berubah dengan terbentuknya jaringan ikat retikulin, penyakit ini juga disebut dengan pneumokoniosis non kolagen.

Berdasarkan analisis paparan debu yang dilakukan oleh PT XXX pada tahun 2017 pengambilan data dengan mengunakan Low Volume Air Sampler (LVAS) yang diambil di 4 titik yaitu memiliki nilai $1,7-2,0 \mathrm{mg} / \mathrm{m}^{3}$. Hasil penelitian dibandingkan dengan Peraturan Menteri Tenaga Kerja dan Transmigrasi No.13 Tahun 2011 dengan nilai ambang batas sebesar $1 \mathrm{mg} / \mathrm{m}^{3}$.

\section{PENUTUP}

Dari hasil analisis paparan debu di PT XXX, paparan debu tidak sesuai atau berada di atas nilai amban batas yang telah ditetapkan. Oleh karena itu perlu dilakukan tindakan atau upaya pengendalian debu, salah satu cara yang dapat digunakan adalah memasang alat penyiraman air otomatis di beberapa titik di daerah produksi. 
JURNAL KARYA TEKNIK SIPIL, Volume 4, Nomor 1, Tahun 2015, Halaman 126 - 134, Universitas Diponogoro, Semarang.

Khumaidah. 2009, Analisis Faktor-faktor yang Berhubungan dengan Fungsi Paru terhadap Pekerja Mebel PT Kota Jati Furindo Desa Suwawal Kecamatan Mlonggo Kabupaten Jepara, Semarang : Badan Penerbit Universitas Diponegoro, Semarang.

Peraturan Menteri Tenaga Kerja dan Transmigrasi No.13 Tahun 2011 tentang Nilai Ambang Batas Faktor Fisika dan Faktor Kimia Di Tempat Kerja.

Qosthalani, Fildzah Alfita.2014. Metode Gravimetri dalam Alat High Volume Air Sampler (HVAS) Sebagai Cara Kuantitatif Mengukur Kualitas Debu dalam Udara. Depok.

Silalahi, MDS. 2013. Kajian Sistem Manajemen Keselamatan dan Kesehatan Kerja di PT Asahima Flat Glass Tbk, Jakarta. Indonesian Jurnal of Urban and Environmental Technology. Vol. 6 No. 4.

Sintorini, MM. 2010. Analisis Kesehatan Dan Keselamatan Kerja (Studi Kasus Pertamina EP Field Jatibarang, 2005-2010). Indonesian Jurnal of Urban and Environmental Technology. Vol. 5 No. 4. DOI: http://dx.doi.org/10.25105/urbanenvirotech.v5i4.684

Sintorini, MM. 2012. Analisis Risiko Kesehatan dan Keselamatan Kerja (K3) di PT Yuasa Battery Tangerang, Indonesia. Indonesian Jurnal of Urban and Environmental Technology. Vol. 6 No. 1. DOI: http://dx.doi.org/10.25105/urbanenvirotech.v6i1.700

Sintorini MM. 2013. Kajian Sistem Manajemen Keselamatan dan Kesehatan Kerja di Pabrik Kelapa Sawit PT Stelindo Wahana Perkasa, Belitung Timur. Indonesian Jurnal of Urban and Environmental Technology. Vol.6 No. 4.

DOI: http://dx.doi.org/10.25105/urbanenvirotech.v6i4.705

Suma'mur, P.K, 2009. Higiene Perusahaan dan Kesehatan Kerja. CV Sagung Seto. Jakarta Tampubolon, T.W, 2015. “Analisis Indeks Kinerja Pekerjaan Produksi Beton Pracetak Sistem DPI (Studi kasus Proyek Aeropolis Crystal Residence". Jurnal Universitas Bina Nusantara. 